\title{
Genetic Variability, Character Association and Path Coefficient Analysis in Radish (Raphanus sativus L.)
}

\author{
M. Z. Ullah ${ }^{1 *}$, M. J. $\operatorname{Hasan}^{2}$, A. H. M. A. Rahman ${ }^{3}$ and A. I. Saki ${ }^{4}$ \\ ${ }^{I}$ Energypac Agro Ltd., Monipur, Hotapara, Gazipur, Bangladesh \\ ${ }^{2}$ Hybrid Rice Project, Bangladesh Rice Research Institute, Gazipur-1701, Bangladesh \\ ${ }^{3}$ Ph.D. Fellow, Banagabandhu Sheikh Mujibur Rahman Agril. University, Gazipur-1706, Bangladesh \\ ${ }^{4}$ Bangladesh Agricultural Development Corporation, Madhupur, Tangail, Bangladesh \\ *Corresponding author and Email: zahirsau@gmail.com
}

Received: 23 August $2009 \quad$ Accepted: 17 March 2011

\begin{abstract}
Genetic variability, correlation and path coefficient analysis of yield and yield contributing traits in twenty one varieties of radish were studied. Root length, leaf length and root yield showed high genotypic coefficient of variation and heritability with high genetic advance in percentage of mean. The highest genetic advance was observed in root yield. Root yield had significant and positive correlation with days to harvest, root length and root diameter, and showed only positive correlation with plant height and leaf width. Path coefficient analysis revealed that plant height had the maximum positive direct effect on root yield followed by root diameter, leaf width and days to harvest.
\end{abstract}

Keywords: Genetic variability, radish, heritability, correlation, path analysis, root yield.

\section{Introduction}

Radish (Raphanus sativus L.) is an ancient crop, native to the eastern Mediterranean and the Middle East, although some taxonomists consider China as the centre of origin (Werth, 1937; Rubatzky and Yamaguchi, 1997). The first records about radish consumption in human nutrition date back to about $2000 \mathrm{BC}$ in the ancient Egypt, whereas its cultivation started in China and Korea about 400 BC (George and Evans 1981; Kaneko and Matsuzawa, 1993). Its economic importance is high and increasing. It is an important vegetable in Japan, Korea, China, India, and other East Asian countries (Kaneko and Matsuzawa 1993). It is an important winter vegetable grown all over the Bangladesh. The edible portion of the crop is its fleshy root which is used as salad and vegetables while the tender leaves are used as vegetables.
Raphanus sativus $(2 \mathrm{n}=2 \mathrm{x}=18)$ is normally a self-incompatible, insect pollinated crop (Rubatzky \& Yamaguchi, 1997). However, by rupturing the stigma surface or by applying pollen to the conducting tissue of style, it is possible to obtain normal seeds by selfing. Normal seeds may also be obtained by bud pollination (George \& Evans, 1981). Cultivars have also been developed and maintained as open pollinated, out crossing populations (Crisp, 1976; Simmonds, 1979).

Root yield of radish is complex, highly variable and is associated with a number of component characters. Information on genetic variability and character association is a prerequisite for initiating a successful breeding program aiming to develop high yielding varieties. Genetic associations provide basic criteria for selection and leads to directional model based on yield and its components in the field experiments (Fraser 
and Eaton, 1983). Path coefficient analysis on the other hand, is an efficient statistical technique specially designed to quantify the inter-relationships of different components and their indirect effects on root yield (Rao et al., 1997). The information on nature of associations and path-coefficient analysis are meager in this crop. Therefore, the present study was undertaken to find out and establish suitable selection criteria for higher root yield through study of genetic heritability, variability, genetic advance and relationship between yield and its components in radish.

\section{Materials and Methods}

The experiment was conducted at the Research \& Development farm of Energypac Agro Ltd, Monipur, Gazipur during Rabi season 20092010. Experimental materials consisted of twenty one genotypes of radish collected from different locations of Bangladesh, India and China. Seeds were sown on 5 October, 2009. The experiment was laid out in a Randomized Complete Block (RCB) Design with three replications. The plot size was $5 \mathrm{~m} \times 1.5 \mathrm{~m}$ with three rows per plot. The distance between rows was $40 \mathrm{~cm}$ and between plants was $20 \mathrm{~cm}$. Data were recorded on eight characters such as plant height $(\mathrm{cm})$, days to harvest, root length $(\mathrm{cm})$, root diameter $(\mathrm{cm})$, leaf length $(\mathrm{cm})$, leaf width $(\mathrm{cm})$ and root yield $(\mathrm{g})$.

Fertilizers were applied at 250, 200, 150, 100, 15 and $12 \mathrm{~kg}$ per hectare as urea, TSP, MP, gypsum, zinc sulphate and borax, respectively. All the fertilizers except urea were applied during land preparation. Urea was top dressed at 15-20 and 30-35 days of after seed sowing. Genotypic and phenotypic coefficients of variation were estimated as per Singh and Chaudhary (1979). The broad sense heritability and genetic advance as percent of mean were calculated as prpposed by Jonson et al. (1955). Normal Pearson correlation was calculated using SPSS 10.0 software. Genotypic and phenotypic correlation coefficients were calculated following Miller $e t$ al. (1958). Path coefficient analysis was estimated according to the method suggested by Dewey and Lu (1959).

\section{Results and Discussion}

\subsection{Genetic variability}

The estimates of coefficient of variation (CV\%), genotypic variance $\left(\sigma^{2} \mathrm{~g}\right)$, phenotypic variance $\left(\sigma^{2} \mathrm{p}\right)$, genotypic coefficient of variation (GCV), phenotypic coefficient of variation (PCV), heritability $\left(h^{2} b\right)$ and genetic advance in percent of mean for different characters are shown in Table 1. The coefficient of variation indicated the presence of significant variability among the varieties in respect of different traits under study. The phenotypic variance $\left(\sigma^{2} p\right)$ or phenotypic coefficient of variation (PCV) was slightly higher than genotypic variance $\left(\sigma^{2} \mathrm{~g}\right)$ or genotypic coefficient of variation (GCV) for all the characters indicating the presence of environmental influences to some extent in the expression of the characters. Similar results were also found by Rabbani et al. (1998) in radish and Rahman et al. (2003) in tomato. Relatively higher value of genotypic $\left(\sigma^{2} g\right)$ and phenotypic $\left(\sigma^{2} p\right)$ variance were found for root yield per plant, leaf length and plant height. GCV was the highest for root yield per plant followed by leaf width, root length and leaf length indicating higher degree of genetic variability in these traits. High heritability coupled with high genetic advance were observed for root yield, root length, leaf length and days to harvest indicating the presence of additive genes, which would be effective for selection a better line of radish. Johnson et al. (1955) suggested that heritability and genetic advance should always be considered jointly during selection of a suitable line or progeny. Howlader et al. (1995) observed the higher heritability for the number of days to root harvest, suggesting the possibility of selection in early generations for this trait. The parameter plant height, root diameter and leaf width showed lower heritability coupled with lower genetic advance which suggest limited scope for improvement of these traits through selection. 
Table 1. Genetic parameters of different yield and yield contributing characters of radish

\begin{tabular}{ccccccccc}
\hline Characters & Mean & CV $(\%)$ & $\sigma^{2} \mathrm{~g}$ & $\sigma^{2} \mathrm{p}$ & $\mathrm{GCV}$ & $\mathrm{PCV}$ & $\mathrm{h}^{2} \mathrm{~b}(\%)$ & $\begin{array}{c}\text { GA }(\% \\
\text { Mean })\end{array}$ \\
\hline PH & 51.222 & 6.22 & 15.81 & 25.97 & 7.76 & 9.95 & 60.88 & 12.47511 \\
$\mathrm{DH}$ & 42.487 & 2.75 & 4.31 & 5.67 & 4.89 & 5.60 & 75.99 & 8.779156 \\
$\mathrm{RL}$ & 18.947 & 7.07 & 7.30 & 9.09 & 14.26 & 15.91 & 80.27 & 26.28384 \\
$\mathrm{RD}$ & 3.756 & 9.26 & 0.10 & 0.22 & 8.23 & 12.39 & 44.17 & 11.18211 \\
LL & 32.253 & 7.44 & 21.04 & 26.80 & 14.22 & 16.05 & 78.50 & 25.95107 \\
LW & 8.698 & 13.44 & 1.66 & 3.03 & 14.80 & 20.00 & 54.81 & 22.53392 \\
$\mathrm{RY}$ & 179.076 & 7.86 & 1748.62 & 1946.53 & 23.35 & 24.64 & 89.83 & 45.59517 \\
\hline
\end{tabular}

$\mathrm{PH}=$ Plant height $(\mathrm{cm}), \mathrm{DH}=$ Days to harvest, $\mathrm{RL}=$ Root length $(\mathrm{cm}), \mathrm{RD}=$ Root diameter $(\mathrm{cm}), \mathrm{LL}=$ Leaf length $(\mathrm{cm}), \mathrm{LW}=$ Leaf width $(\mathrm{cm}), \mathrm{RY}=$ Root yield/plant $(\mathrm{g}), \mathrm{CV}(\%)=$ Coefficient of variation, $\sigma^{2} \mathrm{~g}=$ Genotypic variance, $\sigma^{2} \mathrm{p}=$ Phenotypic variance, GCV $=$ Genotypic coefficient of variation, PCV = Phenotypic coefficient of variation, $\mathrm{h}^{2} \mathrm{~b}=$ Heritability (Broad sense) and GA $(\%)=$ Genetic advance in percent of mean.

\subsection{Character association}

Pearson correlation analysis among seed yield and its contributing characters are shown in Table 2. For clear understanding correlation coefficients are separated into genotypic and phenotypic level in Table 3. The genotypic correlation coefficients in most cases were higher than their phenotypic correlation coefficients indicating the genetic reason of association. In some cases phenotypic correlation coefficient were higher than genotypic correlation indicating suppressing effect of the environment which modified the expression of the characters at phenotypic level. Same results were found by Sharma and Kanaujia (1995) in radish and Afroza et al. (2004) in mustard.

Root yield per plant was significantly and positively associated with days to harvest, root length and root diameter. Similar association was also reported by Panwar et al. (2003), Danu and Lal (1998) and Murali et al. (1998). Only positive correlation was found in plant height and leaf diameter and negatively correlated with leaf length. This indicates that root yield per plant would be decreased with the increase of leaf length. Leaf length and leaf diameter were significantly and positively correlated with plant height. Root length and root diameter had significant and positive correlation with days to marketable root harvest. This indicates that root length and root diameter would be increased with the increase is days to marketable root harvest. Leaf length was negatively associated with root length and root diameter and significant positively correlated with leaf width. It is indicated that root length and root diameter would be decreased with the increase of leaf length and also indicated that leaf width would be increased with the increase in leaf length. 
Genetic variability and path coefficient analysis in radish

Table 2. Pearson correlation coefficient among yield and yield contributing characters in radish

\begin{tabular}{ccccccc}
\hline Characters & DH & RL & RD & LL & LW & RY \\
\hline PH & -0.126 & 0.242 & 0.024 & $0.817^{* *}$ & $0.523^{* *}$ & 0.243 \\
DH & & $0.370^{* *}$ & $0.264^{*}$ & $-0.359^{* *}$ & -0.055 & $0.392^{* *}$ \\
RL & & & 0.218 & $-0.351^{* *}$ & -0.058 & $0.679^{* *}$ \\
RD & & & -0.084 & 0.071 & $0.646^{* *}$ \\
LL & & & & $0.557^{* *}$ & -0.165 \\
LW & & & & & 0.118 \\
\hline
\end{tabular}

** Correlation is significant at the $1 \%$ level (2-tailed).

* Correlation is significant at the $5 \%$ level (2-tailed).

$\mathrm{PH}=$ Plant height $(\mathrm{cm}), \mathrm{DH}=$ Days to harvest, $\mathrm{RL}=$ Root length $(\mathrm{cm}), \mathrm{RD}=$ Root diameter $(\mathrm{cm}), \mathrm{LL}=$ Leaf length $(\mathrm{cm}), \mathrm{LW}=$ Leaf width $(\mathrm{cm})$ and RY $=$ Root yield/plant $(\mathrm{g})$.

Table 3. Genotypic and phenotypic correlations among yield and yield contributing characters in radish

\begin{tabular}{|c|c|c|c|c|c|c|c|}
\hline \multicolumn{2}{|c|}{ Characters } & \multirow{2}{*}{$\begin{array}{c}\mathrm{DH} \\
-0.298\end{array}$} & \multirow{2}{*}{$\frac{\mathrm{RL}}{0.105}$} & \multirow{2}{*}{$\begin{array}{c}\mathrm{RD} \\
-0.097\end{array}$} & \multirow{2}{*}{$\frac{\mathrm{LL}}{0.808^{* *}}$} & \multirow{2}{*}{$\frac{\mathrm{LW}}{0.848 * *}$} & \multirow{2}{*}{$\begin{array}{c}\text { RY } \\
0.185\end{array}$} \\
\hline PH & G & & & & & & \\
\hline & $\mathrm{P}$ & -0.122 & 0.242 & 0.021 & $0.819 * *$ & $0.527 *$ & 0.243 \\
\hline \multirow{2}{*}{$\mathrm{DH}$} & G & & $0.443 *$ & $0.525^{*}$ & $-0.522 * *$ & -0.087 & $0.461 *$ \\
\hline & $\mathrm{P}$ & & 0.389 & 0.294 & -0.364 & -0.048 & 0.403 \\
\hline \multirow{2}{*}{ RL } & $\mathrm{G}$ & & & 0.290 & $-0.502 *$ & -0.070 & $0.711 * *$ \\
\hline & $\mathrm{P}$ & & & 0.210 & -0.350 & -0.052 & $0.677 * *$ \\
\hline \multirow{2}{*}{$\mathrm{RD}$} & $\mathrm{G}$ & & & & -0.266 & 0.162 & $0.875^{* *}$ \\
\hline & $\mathrm{P}$ & & & & -0.082 & 0.080 & $0.647^{* *} *$ \\
\hline \multirow{2}{*}{ LL } & $\mathrm{G}$ & & & & & $0.770 * *$ & -0.263 \\
\hline & $\mathrm{P}$ & & & & & $0.554 * *$ & -0.162 \\
\hline \multirow{2}{*}{ LW } & $\mathrm{G}$ & & & & & & 0.117 \\
\hline & $\mathrm{P}$ & & & & & & 0.129 \\
\hline
\end{tabular}

$*, * *=$ Significant at $5 \%$ and $1 \%$ level, respectively.

$\mathrm{PH}=$ Plant height $(\mathrm{cm}), \mathrm{DH}=$ Days to harvest, $\mathrm{RL}=$ Root length $(\mathrm{cm}), \mathrm{RD}=$ Root diameter $(\mathrm{cm}), \mathrm{LL}=$ Leaf length $(\mathrm{cm}), \mathrm{LW}=$ Leaf width $(\mathrm{cm})$ and RY $=$ Root yield/plant $(\mathrm{g})$. 
Table 4. Path coefficient analysis showing direct (bold) and indirect effects of yield components on seed yield in radish

\begin{tabular}{cccccccc}
\hline Characters & PH & DH & RL & RD & LL & LD & $\begin{array}{c}\text { Pearson } \\
\text { Correlation } \\
\text { with yield }\end{array}$ \\
\hline PH & $\mathbf{1 . 2 3 1}$ & -0.004 & -0.043 & 0.012 & -1.016 & 0.062 & 0.243 \\
DH & -0.155 & $\mathbf{0 . 0 3 2}$ & -0.065 & 0.140 & 0.446 & -0.006 & $0.392^{* *}$ \\
RL & 0.297 & 0.011 & $\mathbf{- 0 . 1 7 8}$ & 0.116 & 0.436 & -0.006 & $0.679 * *$ \\
RD & 0.029 & 0.008 & -0.038 & $\mathbf{0 . 5 3 4}$ & 0.104 & 0.008 & $0.646 * *$ \\
LL & 1.005 & -0.011 & 0.062 & -0.044 & $\mathbf{- 1 . 2 4 4}$ & 0.066 & -0.165 \\
LD & 0.643 & -0.001 & 0.010 & 0.037 & -0.692 & $\mathbf{0 . 1 1 9}$ & 0.118 \\
\hline
\end{tabular}

Residual effect $\mathrm{R}=0.4948$.

$\mathrm{PH}=$ Plant height $(\mathrm{cm}), \mathrm{DH}=$ Days to harvest, $\mathrm{RL}=$ Root length $(\mathrm{cm}), \mathrm{RD}=$ Root diameter $(\mathrm{cm}), \mathrm{LL}=$ Leaf length $(\mathrm{cm})$ and $\mathrm{LD}=$ Leaf diameter $(\mathrm{cm})$.

\subsection{Path analysis}

In path coefficient analysis, the plant height showed the highest positive direct effect on root yield (Table 4) followed by root diameter and leaf width. It is indicated that taller plants with greater root diameter are the important morphological characters for producing higher root yield. Negative direct effect was observed for leaf length and root length with yield. The highest positive indirect effects on root yield were obtained by leaf length, leaf diameter and root length through plant height. Mishra et al. (1987) suggested the importance of the characters for improving yield owing to their positive indirect effects. Days to harvest and root length have positive indirect effects on root yield through leaf length and also they have significant positive correlation with root yield. It is evident that the correlations between yield and the various characters have been partitioned into direct and indirect effect. Here, the correlation coefficient is positive, but the direct effect is negative. Therefore, the indirect effects seem to be considered simultaneously.

Residual effects (0.4948) indicated that the characters which were selected in this study contributed $51 \%$ to the yield. In the present study, this residual effect towards yield might be due to other characters which were not studied in path analysis, environmental factors and sampling errors.

\section{Conclusions}

In correlation and path coefficient analysis, it is reveled that plant height, root length, leaf length, days to harvest and root yield are the most important yield components in radish. These characters also showed the high genotypic coefficient of variation and heritability and also high genetic advance in percent of mean. It is concluded that these components are important for determination of yield which should be given priority in the selection program and as well as for variety development.

\section{References}

Afroza, R., Sharif, M. S. H. and Rahman, L. 2004. Genetic variability, correlation and path analysis in mustard and rape (Brassica spp.). Bangladesh Journal of Plant Breeding and Genetics, 17(1): 5963.

Crisp, P., 1976. Trends in the breeding and cultivation of cruciferous crops. In: The biology and chemistry of the cruciferae (eds.) J. G. Vaughan, A. J. MacLeod and B.M.G. Jones, Academic Press, London \& New York, 69-117 pp. 
Danu, N. S. and Lal. S. D. 1998. Correlation studies in radish (Raphanus sativus L.). Progressive Horticulture. 30(3/4): 135138.

Dewey, D. R. and Lu, K. I. 1959. A correlation and path coefficient analysis of components of created wheat grass seed production. Agronomy Journal. 515-518.

Fraser, J. and Eaton, G. W. 1983. Application of yield component analysis to crop research. Field Crop Abstract, 36 : 787-797.

George, R. A. T., Evans, D. R. 1981. A classification of winter radish cultivars. Euphytica, 30:483-492.

Howlader, M. S. H., Mian, M. A. K. and. Bhowmik, A. 1995. Genetic analysis in radish (Raphanus sativus L.). Annals of Bangladesh Agriculture, 5(1): 9-13.

Jonson, H. W., Robinson, H. F. and Comstock, R. E. 1955. Estimates of genetic and environmental variability in soybean. Agronomy Journal, 47(7): 314-318.

Kaneko, Y. and Matsuzawa, Y.1993. Radish (Raphanus sativus L.). In: Genetic Improvement of Vegetable Crops, (eds.) G. Kalloo and B.O. Bergh, Pergamon Press Ltd. Oxford, England, 487-505, pp.

Miller, P. A., Williams, C., Roginson, H. F. and Comstock R. E. 1958. Estimates of genotypic and environmental variance and covariance and implication in section. Agronomy Journal, 50: 126-131.

Mishra, R., Singh, P., Singh, I. B. and Kumar, S. 1987. Path analysis of the factors contributing to seed yield in yellow seed Indian mustard. Farm Science Journal, 2 (1): 88-91.

Murali, K., Reddy, N. S., Anjanappa, M. and Krishnappa, K.S. 1998. Correlation studies in radish (Raphanus sativus L.).
Karnataka Journal of Agricultural Sciences, 11(4): 1140-1141.

Panwar, A. S., Kashyap, A. S. and Bawaja, H. S. 2003. Correlation between yield and yield parameters in radish (Raphanus sativus L.). Indian Journal of Hill Farming, 16(1/2): 53-55.

Rabbani, N. A., Murakami, Y., Kuginuki, Y. and Takayanagi, K. 1998. Genetic variation in radish (Raphanus sativus L.) germplasm. Genetic Resources and Crop Evolution, 45(4): 307-316.

Rahman, M. A., Alam, M. S., Ahmed, Q. N., Khan, M. A. I. and Mahbub, A. A. 2003. Genetic analysis on yield and its component traits of Tomato (Lycopersicon esculentum Mill.). The Agriculturists, 1(1): 21-26.

Rao A., Khan, M. A., McNeilly, T. and Khan, A. A. 1997. Cause and effect relations of yield and yield components in rice (Oryza sativa L.), Journal of Genetics \& Breeding, 51: 1-5.

Rubatzky V. E. and Yamaguchi, M. 1997. World Vegetables: Principles, Production, and Nutritive Values. 2nd Edition, Chapman \& Hall, USA, 843 p.

Sharma,S. K. and Kanaujia, S. 1995. Association of physical characters with seed yield in radish. Annals of Agricultural Research. 16(4): 487-489.

Simmonds, N. W., 1979. Principles of crop improvement. Longman, New York.

Singh R. K. and Chaudhary, B.D. 1979. Biometrical methods in quantitative genetic analysis. Kalyani publication, New Delhi, $120 \mathrm{p}$.

Werth E. 1937. Abstammung und Heimat des Rettichs. Angew Botany 19:194-205. 